\title{
Learning leadership? Elite Ugandan students and late colonial politics
}

\author{
Carol Summers
}

One of the most pervasive critiques of Britain's record in the Uganda Protectorate came from highly educated Baganda closely tied to the protectorate's institutions: they condemned Britain as a bad teacher.

Whether Britain taught poorly because it failed to start early and to set high standards, because its mission schools were inadequate in selecting and shaping a new leadership, or because it was simply alien, tentative, and insufficiently committed and engaged, the results were what mattered. When Ugandan nationalists called for independence in the 1940s and 1950s and British officials hesitated, the Ugandans pointed out the years that the British had had in which to guide and teach but had failed to do so. If they had not done it yet, why think they would in the future? Pedagogy was a central element in Uganda's anti-colonial politics. The Uganda National Congress began in the late 1940s and escalated through the 1950 s in recognizing experiential education in governance as the necessary path forward. They sought not the 'appropriate' education of colonial educationists' community development schemes, but the practice inherent in heading a ministry or running a district. They had few - if any - doubts about their ability to succeed. They knew they could do better than the British, and if they needed professional experts, they would hire them.

\section{Background and sources}

Uganda's history of literacy and formal schooling was distinctive. Within colonial Uganda, and especially within the central kingdom of Buganda, local leaders maintained control over mission and protectorate primary and secondary schools, and even influenced (and fought over) the establishment of the East African University College at Makerere. Literate, wealthy, powerful Baganda effectively sought and sponsored schooling in Buganda and beyond, and defined the society within Buganda's schools. Those who sponsored, built and held Buganda's schools were neither figureheads nor dupes. They vigorously rejected specific initiatives from missions and the protectorate government that they considered inappropriate, up to and including powerful and influential ideas of modernist development and appropriate community education. This distinctive educational background and the overt activism and power of Uganda's educational leaders meant that it is possible here to tell a history of education's political rhetoric and significance in colonial Uganda that will complement

Carol Summers holds the Samuel Chiles Mitchell-Jacob Billikopf Chair of History and is Professor of Global Studies at the University of Richmond. Her research has focused on education and development policies in colonial Zimbabwe and on radical politics in late colonial Uganda. Email: Lsummers@richmond.edu 
more conventional depictions of structural, bureaucratic growth of a colonial, mission-based school system (Ssekamwa 1997; Tiberondwa 1998 [1977]).

By the late nineteenth century, a few Ugandans were literate, and were writing for themselves as they published history and ethnography, toured Britain, or simply cultivated local authority within the protectorate (Rowe 1989). Notable men had faith in the power of education for their sons, and invested heavily in both the construction and growth of elite institutions within Buganda such as King's College Budo, and by sponsoring promising young men to study in England, Ceylon, South Africa and the United States. Unsurprisingly, both mission and protectorate officials at times viewed this remarkable level of investment and achievement with suspicion, and patronizingly disparaged high-achieving educated Ugandans who earned degrees and failed to fit easily into the racial hierarchies of the empire (Earle 2012). The success of these nineteenth-century leaders, however, was essential to the emergence of new forms of education in the twentieth century, funded by local resources and building on older precedents about how education worked.

Here, instead of retelling a classic story of imperial control and the resistance and frustration of ambitious educated Africans, I examine materials from within the waning years of the Uganda Protectorate that illuminate the ways in which the education and lives of educated Ugandans, whose status was partly a function of their effective association with British institutions, shaped the most anti-British and anti-colonial form of activism in the protectorate. Education, for these men, was a weapon in their individual and collective struggles to become leaders and shape Uganda's future. Whether as students or as alumni, educated men built distinctive approaches to state power through the political, social and economic contexts of schooling and schools.

My perspective on Ugandans' educational discourse builds on my previous work on the history of education in colonial Zimbabwe. During that project, I hoped that within the educational sector, where policymakers, activists and protesters documented compulsively, it would be possible to pay attention to the nuanced ways in which people sought and practised power (Summers 2002). Educational systems documented daily events, debates over practice, and struggles over theory. Such documented details on educational practices, and more abstract rhetoric about education's ideals and goals, provide insight into political imagination and practice.

Distinctive struggles over education, whether in Zimbabwe or Uganda, undermine simplistic categories for understanding colonialism and resistance. Instead, the accretion of case after case, thoroughly documented, of values, initiatives and practices offers an opportunity to think about emergent ways of categorizing what people were doing, and the tools they had to work with. Documentation from colonial Zimbabwe's educational system allowed an examination of how people struggled over leadership, over questions of patronage, over aspirations, and exploitation. In today's language, in and around schooling, Zimbabweans acted as both individual entrepreneurs and as community-building politicians.

As I began to study Ugandan history, I found myself in a context radically different from Zimbabwe's colonial past. But I have sought to remember Zimbabwe's lessons about complicated power. Late colonial politics in Uganda, and perhaps especially in Buganda, fails to fit into conventional frames for understanding change, such as examinations of colonial power and resistance, or the emergence 
of a nationalist leadership. Uganda's experiences of elite alliances with British power and successful economic growth were distinctive. Uganda was not especially underdeveloped or dependent. Its class structure included a contentious elite shaped by meritocratic ideas of achievement that actively used patronage and offered social mobility in a context of ethnic mobilization. Buganda and Uganda insisted on following their own paths of political activism through indigenous ideas of stewardship and citizenship, patronage and accountability, and even, eventually, loyalty and ethnic patriotism (Summers 2005).

To date, my work on Buganda's politics has not emphasized education, schooling, teachers, pedagogy, curricula, or any of the concerns that I focused on in Zimbabwe. Yet even without detailed work on the schools and educational systems of Uganda, the educational sector protrudes into Buganda's politics. Elite Ganda families and patrons invested early, against the advice of protectorate officials, in elite imperial education for promising young men, building an elite fluent in English and with high-level imperial professional qualifications, an elite that rejected any model of cheap, rudimentary schooling. Within Uganda, flagship mission schools, such as King's College Budo and St Mary's Kisubi, were supported by local elites, who donated land and funds. Ugandans' sponsorship of education began in the earliest years of the protectorate and continued as the colonial era proceeded to make schools centres of socialization and networking, especially for those aspiring to chiefships within the kingdom of Buganda's administration. Strikes and clashes at these schools marked shifts in generational expectations, offering microcosms of broader political mobilizations (Summers 2006). The land seizures that were key to the growth of Makerere University both demonstrated the problems of Buganda's colonial Uganda Agreement and triggered the assassination of Martin Luther Nsibirwa (Thompson 2003). And when politics in the kingdom of Buganda blocked or diverted activists' initiatives, politically engaged entrepreneurs and activists founded independent schools that explicitly promised control by African education leaders and the nurturing of specific faiths, political allegiances and professional networks. Further, elite Baganda with cosmopolitan educations returned to Uganda with contacts from their time at Oxford, Cambridge, the University of London's School of Oriental and African Studies and the London School of Economics and Political Science. These returnees became central both to new forms of agitation from the 1930s onwards and to the literal writing of new agreements and constitutions, such as the Namirembe Accords and the Uganda Agreement of 1956.

As told by some of Buganda's most literate and articulate leaders, the country's late colonial politics was a struggle over who was qualified to lead and govern. Buganda's officials were informing the governor at least as early as 1953 that they believed themselves ready for self-rule - and, if not, there was something wrong with Britain's pedagogy. ${ }^{1}$ By 1958, Y. S. Bamutta, speaking to Uganda's Legislative Assembly to advocate for independence, used his usual talking points when he asserted: 'We have been waiting for the last 60 years. You cannot train a child to walk and give it a stick to lean on. That way it will

\footnotetext{
${ }^{1}$ Omulamuzi (Mugwenya) and Kabaka in discussion with the governor, 3 and 6 November 1953, minutes in Colonial Office (CO) 822/567, National Archives of Great Britain (NAGB), Kew, London.
} 
never be able to walk. You must let it try and let it fall down and then it will pick itself up and thus will learn how to walk.'2 Elite Ugandans did not call for an education to nurture the youth, cultivate solidarity or communal culture, or to adapt to local conditions. They put forward harsh but confident visions of Ugandans' readiness as empirical, experiential students of leadership.

Here, I offer three interventions by local intellectuals, all illuminating aspects of Uganda's emergent political crises and the leaders who emerged from them, eventually contributing to nationalism and a path towards independence from Britain. These declarations and practices of education illustrate how Ugandans connected activism, patriotism and achievement to individuals' educational achievements. Elite, educated Ugandans' ideas challenged conventional imperial models of governance rooted in paternalism and social control.

My selections here are neither random nor comprehensive. Others have written on earlier intellectuals, much studied for their early recruitment of missionaries and adoption of literacy as a political tool during the late nineteenth century and into the early twentieth century (Rowe 1989). Alternatively, the decade of the 1960s, when a newly independent nation sought to define itself, offered its own challenges. More recently, Ugandans have vigorously debated education at all levels, from universal primary education to the status of Makerere. In the selections here, I focus simply on the 1930s to the early 1950s, as a new cohort of Ugandans sought to understand and shape their own individual futures as well as Buganda and Uganda.

\section{Education as a weapon for individual success}

First - and the eldest of the three local intellectuals - Yusufu Bamutta (in an undated column) wrote:

All educated men know that to learn is the weapon by which any person could be [more] highly placed than his uneducated countrymen ... the Native of Buganda wants to learn ... Those who can afford to send their children to England for education, let them do so ... We have both Government and Missionary Schools here, they are of course welcome, but once any of them starts to put any obstacles in the way of even those who can afford to send their children abroad by telling them to start with the local language ... if this is tried I say that these institutions will be doomed. We refuse to be dictated to as to what education is fit for us ... Those who cannot afford [to send children abroad] let them by all means go to the local schools which can give them education to meet their requirements but any local white masters who try to interfere in [people's pursuit of the best education] there is trouble ... As far as education goes the educated Muganda knows what is best for his country, we want to be lawyers, Doctors, in fact everything [the] brain can master ... The native of Buganda kingdom knows now what he wants and he means to have it. The Native government should make it a rule to put aside every year some money and this must be a big sum for educating all natives in England, who have shown special progress in their learnings ... Until a Muganda native can meet any European here politically on equal terms, he shall not be satisfied ... [English help is welcome, but] if he tries to give us what they call 'African education' we shall oppose him tooth and nail ... To obtain the highest education, the native must leave his country when young. The talk of natives

\footnotetext{
${ }^{2}$ Legislative Assembly debates, April 1957, in CO 822/1510, NAGB.
} 
coming back 'de-Africanised' is all rubbish and no decent minded Muganda should take this seriously. ${ }^{3}$

It would be possible to simply see Bamutta, in his advocacy of education in Britain, as a man brainwashed by the British to believe in the superiority of Britain and of British schools. But such a reading flatly misinterprets the historical record. Bamutta was an activist and fierce critic of British rule, active in Ugandan politics from at least the 1920s until independence. He was notable as the elected member of Uganda's Legislative Assembly selected by the Ugandan National Congress in 1957 to formally put forward a motion for Uganda's full and immediate independence. Nor was his stance as a leading patriot and anti-imperial politician any sort of change of heart.

Bamutta, far from seeking assimilation, or protection, or help, saw in education a 'weapon' and called on his own people to wield it well, whatever its provenance. Unlike his Kabaka (king), Daudi Chwa, who at this time was decrying 'foreignization' and Buganda's loss of identity (Daudi Chwa 1971 [1935]), Bamutta's column stated that Buganda and its people were, at least potentially, stronger than British ideas. Profoundly liberal and modernist, Bamutta's assertion that '[t]he native of Buganda kingdom knows now what he wants and he means to have it' embraced individual choices and ambitions. It rejected ideas of protection or vulnerability. And it powerfully accepted the possibility of change - even to the point of asserting that the country's Lukiiko should set aside funds to sponsor the international training of such potentially disruptive, catalytic individuals. In the conventional categories labelling philosophies of education, Bamutta was a meritocrat, seeking the education of a talented few whose education would be the weapons they wielded both for equality with Britons and for change.

Bamutta's theories of education fit awkwardly into a resurgent Ugandan politics of cultural identity and Bataka (clan) patriotism. But his analysis even more emphatically rejected the concerns of key members of Britain's Advisory Board on Education in their canonical 'Memorandum on Education Policy in British Tropical Africa' (1923). Bamutta showed no fear of 'detribalization' or loss of culture through education in English and in Britain. For him, education for development was not industrial, agricultural or technical, but political. And he acknowledged no nervousness about inequity or the alienation of educated elites from backward masses.

Learning - fluency in English, professionalism in law and medicine, and confidence in cosmopolitan experiences - was at the core of Bamutta's vision of education and leadership. Notably absent were alternative values of cultural preservation, cohesion and solidarity, democracy, and decorum or respect.

Interestingly, the internationally educated Bamutta himself, and others who were equally successful in the acquisition of international qualifications, did indeed come back to Buganda, bringing ideas, ambitions and plans to lead. Such returnees proved uncomfortably challenging for British administrators, as the administration sought to pay doctors at the same rate as orderlies and resisted allowing returned students such as Ignatius Musazi (St Augustine's College,

\footnotetext{
${ }^{3}$ Yusufu Bamutta papers, Education Box B doc. 39, Africana Collection, Makerere University Library (MUL), Kampala, Uganda.
} 
Cambridge) or Ernest Kalibala (PhD from Harvard) to take positions with pay equivalent to that of their British or Indian rivals. Like Bamutta before him, Musazi, Kalibala and other returned students never entirely fit within the kingdom's older structures. Further, with their cosmopolitan education and connections, they emerged as activists who struggled to manage individual ambition, their sense of what they were due, and the ever changing possibilities of the region's politics.

\section{Education and elite class formation in Uganda}

\section{According to E. M. K. Mulira:}

Mengo High School boys were for the most part a crowd of snobs [as the school was for the sons of chiefs] ... Naturally they roused the envy and animosity of other boys in the country. These poor unfortunate ones resorted instead to academic competition. As for intellectual ability these arrogant snobs were not a match for the poor boys. They lacked miserably a sense of hard work which the poor boys had in plenty ... when it came to pure academic performance as a compensation, which they loved to show off rather loudly, which naturally offended the former's sense of dignity. But in general no harm was done - it was just a stupid process that went on for either party to boast when it thought it excelled the other. ${ }^{4}$

Mulira's school-centred analysis continued, explaining how the country's political divisions in the 1940s could be understood not through conventional forms of class analysis, but by looking at how men's educational affiliations generated divisions and tensions within Buganda and shaped youths' attitudes regarding political offices and power. Students from the two schools went to Budo, he noted, and initially the sons of the less prominent succeeded better academically than the sons of chiefs, whose only resource was snobbishness. Both sides were ultimately brought together in the first year by a system of flogging.

This flogging system had its good side. By the end of the first year all looked upon each other as brothers. In the second year they were once more united to flog the succeeding newcomers, and during their third year they had already known each other long enough that they enjoyed what they termed old age happily together. The trouble came when they left Budo. Here were the sons of the less well-to-do in academic attainment the superiors of their more aristocratic brothers.

Mulira went on to note that those with chiefly backgrounds used family connections to find jobs first. The sons of the less prominent accused employers of asking 'Whose son is he?' and rejecting candidates with undistinguished fathers. Sons of chiefs, he asserted, got hired. But then the situation became complicated. The sons of chiefs could not or did not do the work. 'They had upbringing and opportunity but could not lead.' Mulira explained this by asserting that they lacked the stamina and responsibility inculcated by overcoming childhood challenges.

${ }^{4}$ E. M. K. Mulira, 'The legacy of two schools: being a historical background to the causes of trouble in Uganda, in 1945', written soon after the disturbances of 1945, EMKM KCB 1/1, African Studies Centre, Cambridge University (ASCCU). 
'Their fathers had little time to spend for their homes and children, as [they] were preoccupied by public affairs. Homes of chiefs were busy - club, restaurant, hotel, rec room and court.' The children of elites did not see their eminent fathers, and thus missed the influence of able men who had learned as palace pages, as officials, 'in the hard school of war', and with missionaries. Further, mothers and wives (who in practice headed these households) lacked such preparation. 'They were simple, kindly and loving mothers and provided food.' Thus their children grew without proper discipline and responsibility, but with luxury and servants.

The sons of less prominent men, on the other hand, were not groomed for leadership but their struggles to achieve taught them necessary skills. Some learned self-reliance from struggling parents. Others worked as servants of chiefs, observing the powerful, following orders, and holding responsibility. Such youth 'learned by observing'. They went to school when they were older, more ambitious and more tenacious than their masters' children. And when they got jobs, 'they stuck to them as tenaciously as a tiger. Thus they ended up through sheer ability and hard work with important jobs. They replaced sons of chiefs.' Such hard-working men then continued to challenge chiefs' sons, who achieved through money and personal contacts with Europeans. Mulira's essay concluded that it was an irony of history that schools should become the cause of so much division and suffering within the country. ${ }^{5}$ But he also implied that the very clashes he described provided an opportunity for essential social learning.

Mulira's assessment of elite classes and schools quoted above was an early effort, and far less coherent or incisive than some of his later work. E. M. K. Mulira was a brilliant and markedly well-connected political activist but - perhaps because of his clear vision of the manoeuvring around him, which left him willing to work with everyone and unwilling to wholly reject anything - he was more successful as an analyst than as a political leader. In his autobiography, he discussed his childhood, implying that he came late to school and political success. He emphasized that in his childhood home, all children 'had some specific jobs to do both in the home and in the village. My brothers and I and our sisters took a full part in all this ... kind of training that then was to prepare the young for the future.' ${ }^{6} \mathrm{He}$ described how his father, a retired official from Kooki, on the fringes of Buganda, had trained those within his household, giving each an office, and holding them accountable, setting a young Eridadi to learn household chores, including making butter, caring for children and sewing his own kanzu, and also to learn to make barkcloth, work for a blacksmith, brew beer, build a house, work on a road, and more. Compared to all this, academic skills seemed to come more informally, as his father taught him to read. By the age of twelve, he claimed, he was educated in the traditional sense. 'My schooling was an accident' that came when his family's cattle were dying of plague, and his father realized that a traditional placement with a chief would be less effective than sending a young Eridadi to his siblings. Several sisters were married to men who became school headmasters. All his initial school placements came through sisters, brothers, and their spouses.

\footnotetext{
${ }^{5}$ E. M. K. Mulira, personal papers, ASCCU.

${ }^{6}$ Mulira papers, Eridadi Mulira, EMKM/Gen/1/1, unpublished autobiography, undated, ASCCU.
} 
Mulira's essay on the implications of different sorts of elite schooling and on how new leaders emerged in Buganda, though, offers a subjective depiction of the elite educational groupings of the 1930s and 1940s. Like Bamutta, Mulira was not especially concerned with mass training in literacy or with general efforts to cultivate Christian catechism or bible knowledge. Instead, he wrote about those fit to serve as officials of the kingdom of Buganda, or, possibly, the Uganda Protectorate. He wrote from a somewhat ambivalent perspective, as a brilliant younger son of a retired mid-rank chief (gombolola) who originally came not from Buganda's core but from its periphery (Stonehouse 2012).

In many ways, the most coherent aspect of Mulira's critique was an embedded complaint about fathers and inheritance. Elite fathers, who had learned as court pages and in the harsh contexts of war, failed to pass on that learning to their sons. Instead, their example simply offered sons an unsustainable dignity and pattern of consumption. Their sons emulated entitlement rather than the constructive achievement that earned leadership positions. Young men from less elite backgrounds, on the other hand, experienced work and may have had to do service as pages and servants. In doing so, they learned the ingredients of achievement - both practical and academic. Their experience of learning was a more low-class activity of desperate study and scrambling. Copying them, for the elite, would be the equivalent of chiefs' sons modelling themselves on servants rather than on their high-status fathers. Students of leadership thus constituted a new class of achievers, rather than inheritors.

Mulira's critique of fathers and his startling defence of flogging - the violent hazing at the country's most elite school (which he himself evaded) - is thus less sadistic resentment than an assertion that even at the elite levels, people learn through 'training' and example, not just schooling. Discipline, deference, consumption habits and learning in order to take on a new duty or succeed in a new context were key to Mulira's concept of education. Fathers whose sons lacked those disciplines had failed their sons (although Mulira's autobiography made clear that his own father was not one of these), and sons who did not understand the need to work for status failed to understand the country's needs and its continued existence as a meritocracy of achievement, rather than descent.

Mulira wrote his essay not as a student, or as an official, but as a devout Christian teacher, appointed to top-level positions in Budo school, and, after its upheaval, elsewhere. He went on, after a stint in London, to a relatively wellpaid job as a research assistant at the East African Institute for Social Research at Makerere, which he eventually resigned from as his political involvement intensified.

Mulira's analysis of fathers' failure and his advocacy of what today might be called 'experiential learning' was not about creating colonial subjects or labourers. His discussion of Budo, after all, defended violent hazing that initiated new students into a group of leaders, not routinized 'fagging' or the requirement for junior scholars to be longer-term servants of senior house members. Overall, Mulira emphasized meritocracy. Elite achievement, rather than any privileged class of aristocratic inheritance, was key to Buganda's future. Where Bamutta emphasized education, Mulira differed by emphasizing not the international content and qualifications of schooling, but how the achieving leader needed to understand not simply whose son he was and his place in social networks but, more critically, how to work, achieve and gain peer recognition. For Mulira, 
political achievement was vital but required the ambitious to manage whatever challenge arose, even sewing his own kanzu, doing his own accounting, and managing relationships with his colleagues successfully enough that instead of beating him up, they accepted his authority.

Where Mulira echoed Bamutta significantly, though, was in the absence of any idea that education could or should nurture children. Bamutta advocated sending even very young children far from home, and into the alien environment of British boarding schools with harsh discipline. Mulira acknowledged the competitiveness and flogging of the elite Budo school as 'stupid' and painful - but nevertheless he saw it as socially vital in shaping the leaders the country needed. He was not idiosyncratic in asserting harsh education as a necessary way of both stimulating achievement and binding students together into a whole that would be able to effectively lead the new community. Similar rhetoric emerged during the nationalist period when another activist, Sempa, discussed Makerere University's role in binding together the graduates of the country's diverse schools, putting them under pressure, and fostering new forms of unity (Karugire 1980: 190). Parents' efforts to encourage, nurture or facilitate their children's lives in kindly ways were thus more potentially counterproductive than helpful.

Overall, Mulira's analysis, echoed in Sempa's general discussion, emphasized that students' activism in late colonial Uganda was, indeed, partly about individuals' acquisition of the weapons of education, as Bamutta suggested. But within schools, teacher-training institutions, Makerere University and the new offices graduates occupied, it also provided a new sort of solidarity of achievement that fostered a class of leaders honed in school experiences, and distinct from those who simply inherited status from their fathers. Student activism, from flogging to striking and beyond, brought contentious, ambitious men together and allowed students and graduates to announce their education, practise leadership and pursue change.

\section{New Ugandans and the entrepreneurial possibilities of private schools}

Bamutta, with his British education, and Mulira, with experience in the elite Protestant schools of Buganda (and terms at the London School of Economics), emerged from an early generation of Western-educated men who were alumni of the country's most elite, widely discussed schools. Protectorate education officials and experts generally respected such men's status and achievements. More controversial, though, were private schools, ranging from rural and local to urban and ambitious. Some were simple village schools, sponsored by a Protestant or Catholic evangelist with minimal central support or oversight. A few were more distinctive and were not affiliated with mainline mission churches. Some of these independent schools were founded and owned by educated leaders and activists, such as Ernesiti Kalibala, Spartas Mukasa, and the Bataka Union's leaders. Such private schools did not come from nowhere. Locally owned village schools were widespread in Uganda, especially in Buganda, by the 1930s (Hanson 2010). And as mission funding faltered during the Depression, even prominent schools emerged from strict mission oversight.

Local ownership was not the abstract idea of stakeholders' interest in schools, but a literal statement of fact. By the 1940s, even the Church Missionary Society was in the process of accepting local, non-mission ownership of schools, including 
of leading institutions such as King's College Budo and diocesan schools. This was not, though, a smooth process. Budo, in particular, experienced conflict over what independence meant in 1941, when its teachers' lukiiko (council) asserted that they owned the school. Both Denis Herbert (the school's principal) and the report of the Budo investigation argued that this attitude was at the centre of the clash that began with seventeen Budo masters asserting their authority over the school and signing an 'ultimatum' over changes in school policy. Many of those seventeen masters went on to work at Aggrey Memorial School, an entirely non-mission institution founded by Ernest Kalibala. In Herbert's assessment, as European heads came and went, the African staff saw themselves as Budo school's backbone and centre, and actively resisted his efforts to assume control and institute a more nurturing administration. ${ }^{7}$ Beyond the staff, as further reforms to the school's legal structures proceeded, three prominent men sued the Bishop of Uganda for altering the school's ownership without the permission of Budo's governors, who included the kingdom of Buganda's prime minister and treasurer. ${ }^{8}$ Meetings of critics, who included parents and students' sponsors, told the bishop that he could hand over Budo school to the government only if he paid back funds contributed by Baganda over the years and moved the school from Budo hill. ${ }^{9}$ Mission officials back in London viewed the assertions of ownership by teachers and parents with a degree of disbelief and even incredulity, but a senior missionary rebuked them: 'You say you can't take seriously the suggestion about the staff's idea of discipline (by majority vote). I'm afraid you must do so (and not only in Budo) or you won't be getting a right picture.'10

Struggles over the ownership of schools in Uganda were not generally about students or curriculum, but about staff and sponsors. Founding, cultivating and maintaining a school allowed its owners to demonstrate patronage. School ownership recruited clients and significantly raised owners' status in a context where simply being a teacher was a low-prestige enterprise. Some entrepreneurs, such as Ernest Kalibala, even sought to make a monetary profit with their business courses.

Ernest Kalibala, son of a prominent chief, received some support from the Phelps Stokes Fund and the Church Missionary Society for his advanced schooling. But he rapidly became a critic of the places available in Uganda for an educated African. Like a number of other educated men, he had to deal with accusations of theft and mismanagement, although none came to trial. ${ }^{11}$ By 1935, the mission was complaining that he had refused to settle down, he cost them more than $£ 200$ a year, and he would never be satisfied with less than $£ 350$ a year - a salary equivalent to that of a European missionary at a time

\footnotetext{
${ }^{7}$ Herbert to Hooper, 15 May 1943, and 'strictly confidential' copy, 'Disturbances at King's College Budo', report of the board of enquiry appointed by the Director of Education, March 1943, CMS G3 A7/e1, Church Missionary Society Archives (CMS), Special Collections, Cadbury Library, University of Birmingham.

${ }^{8}$ Protestors included Paul Balintuma, head of the princes, as well as other chiefs. Mass meetings of Budo parents and founders, 2 October 1945, CMS G3A7/e1, CMS.

${ }_{9}$ Mass meeting of Budo parents and funders to Bishop Stuart, 21 April 1943, CMS G3 A7/e1, CMS.

${ }^{10}$ L. B. Greaves to H. M. Grace, 17 April 1943, CMS papers, Birmingham.

${ }^{11}$ Report (English version) of commission appointed to look into accusations of theft by Omuwanika, in response to accusations by Prince Joseph Musanjo, 1928. Ezera Kabali papers, Box AR KA 2/8, Africana Section, MUL.
} 
when Ugandan clergy were earning only $£ 24$ a year. He sought, in the mission's view, a princely salary to serve as the mission's director of education. ${ }^{12}$

Unsuccessful as an employee, Kalibala negotiated unsuccessfully with Serwano Kulubya $^{13}$ and successfully with Prince Suna to found Aggrey Memorial School. From its opening in 1935, Aggrey was a school owned by Africans - Kalibala, Prince Suna and others - and was named after an internationally renowned African educator. It began on a small scale, as one of the private schools that the government viewed as simply profit-making ventures. It closed during World War Two, due to lack of funds and because it was unable to meet the conditions of the Health Department. But in the aftermath of the war and conflict at the protectorate's most prestigious school, King's College Budo, it opened again. Its headmaster, J. G. Zake, complained that:

The Education Department appears to define private schools in a way that implies business concerns for the sole purpose of making private profits. It is not easy to state ... whether these schools are making any profits or not; but it is quite clear that almost all of them are working under conditions which are so difficult that one is inclined to believe that they work for public profit at private loss. ${ }^{14}$

Like other private schools, Aggrey charged fees. Some of its teachers were officially trained and qualified, but others were not. Its facilities were problematic. And its students had to work - making bricks for their own buildings. Buganda's private schools - including Aggrey, its leading independent private school - had very real material limitations, and students recognized the need to struggle to achieve.

For school sponsors, though, that struggle within a school that they themselves owned was part of the process of training and cultivating a new leadership. Aggrey was not simply about individual ambition. By the 1950s, it offered teacher training for those who would go off and found Bataka schools sponsored by political activists. And it provided a central location for the tea parties that cultivated community and kept the Bataka Union alive after its banning in 1949.

Of all the schools in Buganda, it is possible that Aggrey and other private schools came the closest to resembling the 'African education' that Bamutta condemned. They did so both from economic necessity and from ideology. Without the sponsorship of leading Protestant or Catholic chiefs and missions, they were poor. They were chronically short of good teachers. The teachers who were at Aggrey, however, emphasized their ownership and their sense that they were in charge of developing their own school, society and world. They complained that more conventional schools were irrationally sited, intended to allow

\footnotetext{
${ }^{12}$ Williams to Hooper, 8 January 1935 . Williams went on to note that this discrepancy would cause resentment and problems with local clergy if paid, but that the Lukiiko, which had funds to spend, was exacerbating the problem by its willingness to pay high-profile salaries and sponsorships. CMS G3 A7/1/1 v.1, CMS papers, Birmingham.

${ }^{13}$ The resident reported that being turned down for a loan of $£ 500$ to support the school led to Kalibala's lasting animosity towards Kulubya. A. Cox to [illegible], 9 March 1937, Foreign and Commonwealth Office (FCO) 141/18114, NAGB.

${ }^{14}$ J. G. Zake, Headmaster Aggrey School, Memo 78 to the De Bunsen Commission, 1952, AR 35/8, De Bunsen Commission unpublished papers, MUL.
} 
denominations to compete, not to provide education. School leaders called for a form of education that would shape responsible, culturally and politically aware participation in Uganda's economy, and would allow graduates to rise above menial work. Apprenticeships, projects that extended into students' homes, and technical education were part of their plans, and they sought an expansion of secondary education in the trades and agriculture. Overall, they accused other educated Africans of adopting a 'derogatory attitude' towards African culture, and of acting passively, waiting for their fathers to provide for them, rather than seeking the skills to develop the country for themselves. ${ }^{15}$

Aggrey was the most ambitious of the private schools of late colonial Buganda, but it was far from alone. Spartas Mukasa was at least as ambitious as Ernest Kalibala, and equally willing to re-think colonial relationships. His school was apparently part of his effort to develop the Greek Orthodox Church in Buganda. Mukasa's own early experiences had included a stint as a headmaster at the government's Bombo military school. ${ }^{16}$ The tie between evangelizing for a denomination and building a school was tight. Mukasa valued his school even when it provided a lever that the government tried to use to pressure him to give up active engagement in the Bataka Union.

Founded in 1927, Anonya Greek Orthodox School had become, by 1952, a primary institution whose students had an average age of sixteen. ${ }^{17}$ Its head, Spartas Mukasa, was the single most effective and prominent speaker at the Bataka meetings of the late 1940s, where the audience complained when he was not available to sonorously and eloquently read out Semakula Mulumba's regular political denunciations, and where he asserted, among other things, that the people had to make demands - and the government must do what they said. In the trials after the 1949 protests, he was sentenced to sixteen years of hard labour. A confidential report emphasized that Spartas Mukasa was a highly effective speaker and organizer, and in his absence after his proscription, the Bataka movement had no one of equal quality. ${ }^{18}$ Anonya school was part of his political engagement. One of Semakula Mulumba's brothers taught there. ${ }^{19}$ And students as well as teachers were political; mission schools reported intercepting at least some letters written by students from Anonya school to their own pupils, containing 'the usual Bataka propaganda'. ${ }^{20}$

Spartas Mukasa was a successful organizer, and the school he founded exists to this day. Other activists may have been less successful, but they were equally aware that a school offered an opportunity for substantial leadership, and a way of avoiding government sanctions against political activity while recruiting and training followers and clients. Henry Kanyike was a highly political teacher, whose

\footnotetext{
${ }^{15}$ Memo 77, from the teachers of Aggrey School, to the De Bunsen Commission, 1952, AR 35/8, MUL.

${ }^{16}$ Uganda Police periodical intelligence bulletin, 15 October 1941, FCO 141/18105, NAGB.

${ }^{17}$ Memo from Anonya School, Memo 64, De Bunsen Commission, MUL.

${ }^{18} \mathrm{His}$ sentence was reduced on appeal to six years in prison with hard labour. Research Section, Basic Paper, 'The Bataka Party', January 1956, CO 822/85, NAGB.

${ }^{19}$ Biography of Spartas Mukasa, 23 October 1948, FCO 141/18184, NAGB.

${ }^{20}$ The writer noted that there were approximately fifty private schools in Buganda in 1948. The letters were intercepted at St Mary's Kisubi, a leading Catholic school. [Scrawled initials] to governor, 9 July 1948, FCO 141/18183, NAGB.
} 
sermons at Budo school in the early 1940s were blamed for inciting schoolboys against missionary paternalism; he had taught at Aggrey and was deported from Buganda in the aftermath of the 1945 assassination of Prime Minister Martin Luther Nsibirwa. In Mbale, while banned from Buganda, he sought a letter of approval from the district commissioner so that he could go to prominent Indians and seek funds for a school 'like Tuskegee', though independent of Aggrey. ${ }^{21}$

Despite Spartas Mukasa's prominent role in the Bataka movement, and Aggrey's development as a centre around which the Bataka reorganized, neither was simply a Bataka school. Both sought government money and support, and emphasized their educational functions. Rural Bataka schools were different. These small schools (one reportedly had one marginal teacher for more than sixty students, and others had closed when teachers had gone unpaid) are hard to date, but they had begun by at least the late 1940s, as the Bataka movement developed, ${ }^{22}$ and reportedly spread in the 1950 s, when the Bataka party was officially banned. Detractors considered them centres of violent propaganda and military recruitment for the Bataka Union. They received no government support or recognition. A government researcher denounced them as usually run 'by some rabid Bataka supporter', with chronic problems of staffing. Bataka members were 'supposed' to send their children to such schools; however, limited enrolment data suggest that, if they did so, they did not entrust children's entire education to such limited institutions. ${ }^{23}$

The leaders who emerged from Buganda's private schools, whether major institutions such as Aggrey and Anonya, or small Bataka schools, were not students but the teachers and heads. The scramble to put together a private school was challenging. It provided professional status for the new school head, recruited followers, demonstrated leadership, and allowed that individual to voice their own vision of Buganda's future. In forming these schools, their owners and heads sought to demonstrate both conventional and new forms of leadership - the patronage of convention and the entrepreneurialism of the new.

\section{Makerere University}

Education as a weapon, acquired through struggle and allowing an ambitious person to compete not just with technical skill or degrees but with solidarity among the educated, together with the social and cultural insight that could shape a new Buganda and Uganda, remained central to Ugandans' political discourse. Students, as they graduated and became leaders, expected to control and

\footnotetext{
${ }^{21}$ District Commissioner Mbale to Provincial Commissioner Jinja, 20 October 1948, FCO 141/ 18156, NAGB.

${ }^{22}$ Manuscript letter on lined paper, 'The charge against protectorate government for failing to make perfect its promises in 1900 agreement', undated, signed R. K. K. Kerekulya [?]. Namilyongo school is described here as being the centre for training the Bataka army, starting with rifles, and preparing to kill the Katikiro and other leaders who were on the government side. FCO 141/18183, NAGB.

${ }^{23}$ The schools were reportedly mainly political. Uganda Military Intelligence, January 1955, CO 822/85, NAGB.
} 
own educational institutions in their country, whether the independent schools of the countryside, or even Makerere University.

The clash between older styles of landholders and a new, educated leadership was present at the University College's foundation as it acquired its land through a highly controversial act of land seizure. ${ }^{24}$ The university's planners were explicit that Makerere would train leaders, not simply evangelize missionschool boys. They accepted education as a tool for development, if not a weapon. And they expected the stresses of university education to bind together and challenge a new leadership. In some ways, early student protests seemed to be signs of success in this operation. While they did lead to expulsions, they also prompted Uganda's governor to sponsor an expelled activist for a degree in England. ${ }^{25}$ By the late colonial era, Ugandans' political views of education as a battle, or at least a sort of experiential training in struggle, challenged professional educators' pedagogies of cultivating and nurturing malleable youth. Nothing about educational achievement remained apolitical.

\section{Conclusions}

The usual history of education in Buganda and Uganda is a history of government, missions and students. In it, the government provided some money, though never quite enough. Missions ran schools and recruited staff, though never quite successfully. And students constantly demanded more - more and better schools, certificates and opportunities. And in the process, again in conventional depictions of colonialism's effects, students became alienated from their own cultures, inadequate copies of colonial sponsors, and tragically disappointed.

The words and practices of Ugandans involved with education in the latter years of the Uganda Protectorate, though, were strikingly different. They were narratives of achievement - difficult, but successful. Political activism was entwined with educational rhetoric as senior men asserted the ability and need to get an international education from an early age and compete on an equal footing with Europeans; ambitious political analysts sought to understand social tensions within Buganda, between fathers and sons, aristocrats and ambitious commoners, by assessing their experiences of schooling; and entrepreneurs built new political schools and asserted ownership over older ones.

In somewhat jarring statements, Jeh K. S. Mukalazi and Y. B. Buwenbo offered a glimpse of just how distinctive the politics of Buganda's educational rhetoric was. They denounced the education they saw around them as inadequate in training citizens, as it failed to teach students a passion to continue learning after school. They called for more attention to the vernacular and to history, and asserted: 'What we want is an education that will make us acceptable in our African societies as well as in the societies of other foreign people.' But that

\footnotetext{
${ }^{24}$ Buganda's prime minister, Martin Luther Nsibirwa, was assassinated the morning after he forced Buganda's Lukiiko to accept the bill that legalized the land seizure for the university, in 1945.

${ }^{25}$ Governor Andrew Cohen gave Abu Mayanja, a ringleader, a bursary to Cambridge University.
} 
education required higher taxes and also authority for school leaders, as " $[t]$ he Africans learn very well and quickly if there is something threatening them, say punishment. At present, punishments are not advocated in schools, but the tragedy is that DISCIPLINE has shockingly gone down ... we should be prepared to enforce strict discipline.'26

For Buganda's leaders, schools - international, local, government, mission or private - were an opportunity to discipline and to rebel, to learn politics by practice, and to cultivate ownership, citizenship and authority. This form of teaching and learning politics through experience in a demanding and dangerous community was similar to older patterns that commended promising children to fosterage and to apprenticeships as pages and junior wives. The leadership patterns of Buganda - far from being challenged and changed through schooling - were reinforced by schools that Baganda paid for, built, taught in, led and learned from.

Buganda's student and educational politics was not reactive, simply resenting European authority. Students and successful educated men saw education as a way to achieve power. Elite schools and universities were arenas in which students learned to compete, preparing for a meritocratic future of achievement as leaders of the country. And despite any inadequacies in educational content, private schools throughout the country were political institutions that tested their leaders' initiatives, fostered new patronage networks, and allowed those leaders to build and institutionalize professional and personal power as they recruited foot soldiers for political engagement.

Surprisingly, it is possible to sketch a depiction of Buganda and Uganda's late colonial education without ever really needing to engage with top-down colonial initiatives from the Colonial Office or mission development experts who practised what Uganda's activists condemned as bad teaching.

Elite education was a weapon in Uganda. It prepared the country's leaders for power at independence. All clearly understood the need to manoeuvre and mobilize, rather than simply await a grant of independence from an imperial protector. Elite and independent schools, by fostering new solidarities among their graduates and allowing patrons to practise ownership and the control of clients, challenged British authority as students built themselves into new people with new identities, connections and resources.

\section{References}

Daudi Chwa (1971 [1935]) 'Education, civilisation and foreignisation' in D. A. Lowe (ed.), Mind of Buganda. Berkeley CA: University of California Press, 1971.

Earle, J. (2012) 'Reading revolution in late colonial Buganda', Journal of Eastern African Studies 6 (3): 505-26.

\footnotetext{
${ }^{26}$ They also complained that 'Missions have petty policies, where in their schools, teachers are expelled or suspended for very small matters of religion .... a problem to education in general. The mission school owners should be advised to excommunicate the teachers ... but should not suspend or expel him as this is a loss to the country, as well as a shock to the family of the teacher which may be involved into unhappy financial circumstances.' Memo 67, Mr Jeh K. S. Mukalazi and Y. B. Buwenbo, to De Bunsen Committee, MUL.
} 
Hanson, H. (2010) 'Indigenous adaptation: Uganda's village schools, ca. 18801937', Comparative Education Review 54 (2): 155-74.

Karugire, S. R. (1980) A Political History of Uganda. Nairobi: Heinemann.

Rowe, J. (1989) 'Eyewitness accounts of Buganda history: the memoirs of Ham Mukasa and his generation', Ethnohistory 36 (1): 61-71.

Ssekamwa, J. (1997) History and Development of Education in Uganda. Kampala: Fountain.

Stonehouse, A. (2012) 'The Bakooki in Buganda: identity and assimilation on the peripheries of a Ugandan kingdom', Journal of Eastern African Studies 6 (3): $527-43$.

Summers, C. (2002) Colonial Lessons: Africans' education in Southern Rhodesia, 1918-1940. Portsmouth NH: Heinemann.

Summers, C. (2005) 'Grandfathers, grandsons, morality and radical politics in late colonial Buganda', International Journal of African Historical Studies 38 (3): 427-47.

Summers, C. (2006) "Subterranean evil" and "tumultuous riot" in Buganda: authority and alienation at King's College, Budo, 1942', Journal of African History 47 (1): 93-113.

Thompson, G. (2003) Governing Uganda: British colonial rule and its legacy. Kampala: Fountain.

Tiberondwa, A. K. (1998 [1977]) Missionary Teachers as Agents of Colonialism in Uganda. Kampala: Fountain.

\begin{abstract}
In Uganda, teaching and learning were important metaphors for colonial rule, suggesting a benign protectorate under Britain's guidance. Ugandans, though, repurposed images of teaching, studying and educational sponsorship. Drawing on indigenous ideas about effective education as a sort of experiential education in leadership, they perceived student activism as a resource for a new political and social system. Articulate Ugandans sought elite British education as a weapon. Others emphasized the harsh competitiveness of Uganda's elite schools as the basis for new class solidarities. And educated men saw their ownership of schools as a foundation on which to build political followings as they worked to guide the country. Student activism in Uganda emphasized educated Ugandans' individual and collective practice in power and leadership.
\end{abstract}

\title{
Résumé
}

En Ouganda, enseigner et apprendre étaient des métaphores importantes du régime colonial, suggérant un protectorat bienveillant sous la houlette britannique. Or, les Ougandais réapproprièrent l'image de l'enseignement, des études et du mécénat pédagogique. S'appuyant sur l'idée indigène d'une éducation efficace qui serait une sorte d'éducation expérientielle en leadership, ils percevaient l'activisme étudiant comme une ressource promotrice d'un nouveau système politique et social. Les Ougandais éloquents convoitaient l'éducation prestigieuse britannique pour s'en faire une arme. D'autres mettaient l'accent sur la compétitivité acharnée des écoles prestigieuses ougandaises comme le fondement à de nouvelles solidarités de classes. Et les hommes instruits voyaient dans le fait 
de posséder des écoles un moyen d'entretenir un terreau de partisans politiques, dans leur quête de donner une orientation au pays. L'activisme étudiant en Ouganda soulignait la pratique individuelle et collective du pouvoir et du leadership par les Ougandais instruits. 